\title{
6 An Alternative Eurasian Economic Geography: Afghanistan's Role in Long-Distance Trade
}

Much thought and writing about Afghanistan assumes that the country is located in a peripheral manner to global circulations of finance and capital. By contrast, this chapter considers the relationship of mobile Afghan traders to Afghanistan and argues that commercial nodes within Afghanistan act as vital hubs that are rich in the types of capital and commercial personnel critical for long-distance Afghan networks of credit and trade. A consideration of the entangled trajectories of commercial actors and migrants also challenges the depiction of Afghanistan as a onedimensional departure point for migrants. The country instead plays a central role in inter-Asian circulations of goods, capital and people and occupies a critical role in interconnected and multidirectional geographical trajectories of merchants and migrants. Literature focusing on Africa has shown that trading networks and the nodes at which they coalesce can play a critical role in economic development. ${ }^{1}$ Similarly, Afghanistan's trading networks and the nodes important to them inform development across Eurasia in settings where we might least expect them to do so - the arrival of consignments of Chinese commodities in Odessa, for instance, being intimately connected to flows of capital from Afghanistan to Europe and China. In this sense, tracing Afghan trading networks reveals connections between different parts of Eurasia - connections in which Afghans are themselves active in constructing.

The chapter focuses on ethnographic material concerning the intertwined flows of commodities, capital and people, as well as the practices and social relationships implicated in such flows. It seeks to contribute to thinking in the social sciences about the political economy of Eurasian connectivity by addressing a distinction visible in much of the relevant literature between economic geographies regarded as being of central significance and others depicted as peripheral, marginal or 'small scale'. In the expanding body of scholarship on the effects of globalising processes in Eurasia, research tends to focus on either centres of power and economic life or the peripheries of these. At one level, an impressive body

${ }^{1}$ Carrier 2016. 
of literature documents the experiences of mobile actors hailing from Eurasia's economic peripheries in its political and economic centres. Studies of Central Asian migrants in Moscow, of labourers from postsocialist countries in Istanbul and of migrants in China's great economic centres, such as Guangzhou, have enriched our understanding of migration at a Eurasian scale. ${ }^{2}$ At another level, scholars have also recognised the importance of Eurasia's economic peripheries to long-distance trade and commerce. ${ }^{3}$ They have written accounts of the local, national and global imaginaries associated with new Asian transport corridors that link China to Central, South and South East $\mathrm{Asia}^{4}$ and assessed the influence that the Belt and Road Initiative is having on the livelihoods of informal traders operating in China's mountainous borderlands. ${ }^{5}$ The picture of everyday life in Eurasia's globalised hubs and in its economic peripheries that arises from such scholarship adds complexity to the top-down approach of much work in political science and international relations. Anthropologists and scholars in related disciplines have brought attention, instead, to the ways in which the agents of 'globalisation from below' - to use Gordon Mathews' felicitous phrase - are involved in informal forms of economic activity that are of global significance. ${ }^{6}$ The individuals and communities involved in such forms of 'globalisation from below' lead precarious lives that geopolitical projects of Eurasian 'connectivity' and 'development' exacerbate rather than ameliorate. ${ }^{7}$

Studies of 'globalisation from below' have added great nuance to models that construct rigid distinctions between the cores and peripheries of the global economy. ${ }^{8}$ I have suggested thus far, however, that rather than locate the trading networks studied in this book as 'above' or 'below' the nation state, it is helpful to think of them as thriving at the interstices of multiple geopolitical projects of Eurasian connectivity. Taking the perspective of long-distance trading networks and the merchants who form them reveals alternative geographies of Asian connectivity and shines light on the role played by traders in authoring these. Much writing in the field of history and anthropology has uncovered 'alternative' affective and intellectual geographies that question taken-for-granted assumptions about the geographic location of centres of knowledge and learning. ${ }^{9}$ As we have seen in the preceding chapters, focusing on the

${ }^{2}$ Excellent studies in this vein include Bloch 2011, Bodomo 2010, Chu 2019, Matthews, Gordon, Lin and Yang 2018, Matthews, Lins Ribeiro and Alba Vega (eds), 2012, Nikolotov, 2019, Reeves 2016, Sahadeo 2011b.

${ }^{3}$ Zhang and Saxer 2017 and Saxer 2016a.

${ }^{4}$ Rippa and Saxer 2016, Rippa 2019, Saxer 2011, Saxer 2016b.

${ }^{5}$ Mostowlansky and Karrar 2018. $\quad{ }^{6}$ Mathews, Lins Ribeiro and Alba 2012.

${ }^{7}$ Matthews, Lin and Yang 2018 and Cheuk 2016. ${ }^{8}$ Wolf 2010.

${ }^{9}$ Bayly 2007 and Pickett 2013. 
activities of specific trading networks illuminates the significance to these of particular nodes, regardless of their location in dominant geopolitical landscapes. Understanding commercial nodes rests upon an analysis of their multiple significances - economic, cultural and political - for specific networks. Approaching them from this standpoint reveals commercial and geopolitical geographies that are rarely considered important in conventional accounts of Asia's political economy. Yiwu, for example, is a relatively small city that is peripheral to much trade between China and the wider world yet of critical significance to multiple and entwined trading networks.

By actively tracing intermeshing flows of people, things and credit, this chapter illuminates the broader alternative economic geographies that the networks cultivate and across which they operate. I use the term 'alternative geographies' to highlight particular 'circuits of consumption, exchange and production' that rest uneasily within a framework of economic cores and peripheries. ${ }^{10}$ Geographers have deployed the term 'alternative economic geographies' to index modes of organising the economy that either actively resist or are not subsumed within the concept of 'capitalist modernity' and the regulated forms of financial transactions with which it is associated. By focusing on the importance of credit networks to the activities of long-distance commodity traders, this chapter builds on such work yet employs the term in a broader sense than that used by most geographers. It does so for two reasons. First, if it is unhelpful to cast the trading networks under study as opposed to state boundaries or derivative of geopolitical projects, then the economic geographies explored in the chapter are not 'alternative' in the sense that they 'resist' global capitalism. The alterity of the networks is visible, rather, in the ways in which the flows of capital, commodities and commercial personnel they facilitate connect sites and contexts rarely thought of as having wider forms of economic significance. Second, the geographies explored are alternative because they question the dominant ethnic, national and geopolitical categories through which space is widely assumed to be organised. ${ }^{11}$ The circuits of trade and migration described in what follows bring parts of the world into a dynamic relationship with one another, despite the fact that they are rarely if at all examined through the lens of 'regional connectivity', be this in a cultural, economic or political sense.

${ }^{10}$ Leyshon, Lee and Williams 2003. $\quad{ }^{11}$ Nowicka 2012: 13. 


\section{'We've Got No Choice, But Why You Come Here Completely Confuses Us': Yiwu's Afghan Traders at Home in Kabul}

Kabul's wholesale Mandawi market is a commercial centre of national and indeed transregional significance that throngs with traders and customers at all times of the year. This is especially so in the days running up to the Eid holidays, when even pedestrians find it difficult to navigate their way through the narrow alleys and lanes that are used by labourers working in the market to pull barrow loads of commodities from warehouses to retail shops. Located on the southern bank of the Kabul River, the vast area making up Mandawi is sandwiched between the historic Murad Khani neighbourhood (a focus of recent heritage conservation activities by international organisations), key government buildings on the northern bank and the old city neighbourhood of Shur Bazaar (which was home to many of the city's Hindus and Sikhs before the 1990s) to its south. The main artery through the market is Mandawi Road, which runs between Kabul's iconic Cinema Pamir and its famed money exchange market, Sarai Shahzada.

Mandawi itself is a labyrinth of concrete structures - the largest comprising four to five stories - that house shops selling goods on wholesale and offices that act as the Afghanistan bases for trading, transport and money transfer businesses, including those discussed in the context of Yiwu in Chapter 4. The history of these commercial buildings (sarai) varies - some were constructed before the outbreak of conflict in Afghanistan in the late 1970s, though most were built in the 1980 s or after the US-led invasion in 2001. Individual merchants - after whom they are often named - financed most buildings in the market, and the shops inside them are used by traders on the basis of either monthly rental (keraye) or long-term lease (sar qulfi) arrangements. In the sar qulfi (literally 'head key') arrangement, traders make a lump payment to ensure continued access to a property and the business reputation it accrues over several years if not decades. ${ }^{12}$

As with many other markets within and beyond South and West Asia, the Mandawi market is organised into different sectors based on the category of goods for sale. In addition to the (in)famous 'money market' (the Sarai Shahzada), sections of Mandawi are devoted to the sale of cloth and ready-made clothing (mostly manufactured in India and China), rice (mostly imported from India and Pakistan), tea (imported from China and Vietnam) and dried fruits and nuts (including a great deal of Afghan

12 See Rahimi 2019. 
produce as well as goods imported from Iran and beyond). There is also a part of the market (the kah furooshi) devoted to the sale of songbirds, cockerels and pigeons - birds traditionally kept in homes as well as being used in fighting contests. A considerable proportion of the small commodities sold in Mandawi - from toys to stationery, scarves, electronic gadgets and kitchen utensils - are imported to Afghanistan from China by traders such as those we have met in previous chapters of the book.

Above all, the Mandawi is a place of trade and work for many of the people I have come to know while conducting research on Afghan longdistance trading networks. The day starts early - shortly after morning prayers - and merchants dealing in commodities purvey their goods to customers (almost exclusively men) from across Afghanistan. Chinesemade 'pashminas' that are often 'branded' with the names of famous European fashion houses are sold by importers to men who run stores in military camps established by NATO - the scarves are sold to foreign troops stationed in Afghanistan. The trade in toys in the market is also brisk. Yet toy-sellers also require access to considerable warehouse (gudam) space, mostly located in ramshackle areas adjacent to trading offices. Another line of work in which many traders are active is the sale of the type of clothing purchased by the country's many security companies, especially hard-wearing boots - notably the 'Czech' design favoured in the country but now made as 'copies' in China. Commodities such as these are widely available in Kabul's 'Bush bazaar' - a market located close to the centre of Kabul that initially specialised in the sale of goods illegally procured from the American forces stationed in Afghanistan but increasingly evolved into one in which Chinese-made copies of such goods - often procured in Yiwu - were sold by Afghan traders. Traders in the market often come to be closely associated with the commodities in which they deal, being referred to by their fellow merchants as 'Hajji shawl' (hajji chadari) or, more embarrassingly, 'Mr dummy' (aghai choshak), for example.

If it is a site of commerce, hard work and exchange, then Mandawi is also famed for its intense sociality; traders delight in recounting the history of the structures from which they operate and discussing the changes that this part of Kabul has seen over the past decades. A working day in Mandawi is incomplete without plentiful cups of green tea, dishes of seasonal fruits - such as the famed angur-e hussaini (grapes) in the autumn months - and traditional Afghan lunches, either eaten in smoky but exquisite eateries or cooked in pressure cookers outside traders' offices and wholesale shops. If interactions with customers mostly revolve around hard-nosed bargaining about the cost, quality and design of commodities, then conversations over such delicacies are 
often decidedly less commercial in nature. Afghanistan's political dynamics, the security situation in the provinces from which customers are visiting Kabul and the social and economic situation of fellow traders are often the focus of discussion. In my interactions with them, traders would regularly recount their knowledge of the history of the buildings in which we sat - frequently pointing out the shops in which Hindus and Sikhs had run businesses before leaving the country in the 1980s and 1990 s, for example. I was also often reminded to take note of the ethnolinguistic diversity of the personnel working in such businesses: 'He's a Tajik, I'm a Pashtun, there's a Herati over there, and if you'd come two weeks ago we even had a Hazara! The idea that we Afghans don't get along is all made up by you English people. Now make sure you write that in your book!', remarked a partner in one money transfer agency I visited at the invitation of an Afghan trader I had come to know in Yiwu. Traders from a variety of backgrounds and with older and more recent histories of participation in commercial life in Kabul collectively emphasise that the market is a site of historic importance to the country. Traders also emphasise their sharing sensibilities and ethical standards that hold within them the potential for transcending the cultural and political divisions that are so important in Afghanistan.

Traders who have forged commercial and social relationships with one another in Yiwu meet regularly during the course of their visits to Kabul. Traders mostly make such visits to Afghanistan on the weeks on either side of the Eid holidays, an important time of the year to visit family in Afghanistan but also to oversee the operations and accounts of businesses and offices in Kabul. During the four visits I made to Kabul while conducting the research for this book, I spent many afternoons with traders I had initially come to know in Yiwu in a Turkish restaurant popular among traders and officials located in Kabul's New City (shahre naw). The restaurant is a twenty-minute walk past graffiti-daubed blast walls, government buildings, parks and newly built shopping centres to the north of Mandawi. Friendship circles comprising four or five men would regularly assemble over tea, juice and a shisha in the café from the mid-afternoon until just before the onset of darkness, 'the bazaar is so slow I left it to my apprentice', my friends would often remark. Importantly for my research, several traders told me they were able to talk to me more openly in Kabul than in Yiwu. 'We want to talk with you in China', remarked one trader in clothing who is in his late thirties, 'but we are under a lot of pressure - even if we go to the mosque or take some money out of the bank we get a knock on our office doors from the police.'

Traders do not treat return visits to Kabul simply as a momentary break from the pressures of life in China, however. Much of their time in Kabul 
is spent dealing with the difficulties of running a business in Afghanistan, which is especially complex in the context of unannounced closures of border posts (sarhad), changes in Afghan government policy relating to customs duties (gumruk) and frequent attempts by the government and its 'international partners' to restrict the informal trade. Traders must also contend with Kabul's insecure environment, in particular the relatively regular kidnapping (iqtitaf kardan) of merchants for ransom. They also face direct threats from militants in the country, including those identifying as belonging to the Taliban. Militants regularly request traders for contributions to their activities in the form of alms (zakat) or taxes on any land (ushr) of which they might be in possession in their home villages. One trader told me how one of his clients in the southern city of Ghazni had recently been visited by a Taliban representative who had asked him for a monetary contribution to the movement. When the trader said that if he were to make such a contribution he would be investigated by the city's authorities, the Taliban representative replied, 'well, in that case, buy a consignment of motorcycles to be picked up from your shop'.

\section{Doing Fieldwork: A Drive through North-Western Afghanistan}

In addition to documenting and analysing the networks and nodes important for long-distance Eurasian trade in commodities, I am also seeking across this book to offer insights into the ways in which researchers might set to the task of studying vast and geographically dispersed networks and the intersections between these and geopolitical processes. While I spent much of my time in Afghanistan with traders based in Kabul, I also visited locales that had been of historical significance to specific networks. As will have become apparent in the preceding chapters, I conducted fieldwork in a range of nodes that conversations with traders revealed to be especially salient for their commercial activities and social lives. At the same time, I also sought to travel and move with traders between such nodes, documenting shifts in their behaviour, selfpresentations and identities in and across such settings. Conducting fieldwork in this manner required me to adjust my plans in response to data that I gathered over the course of my fieldwork. As we saw in Chapter 3, for example, conversations with Afghans in Yiwu brought Jeddah to my attention as a node of significance in China - it was on this basis that I visited the city and traced connections between Jeddah and Istanbul that were of particular importance to Central Asian émigré merchants. As I now explore, in addition to conducting research in nodes that are of contemporary significance, I also sought to visit sites that were of historic 
significance to the networks under study. Making visits to sites of prior relevance to their activities meant it was possible to arrive at a better understanding of the histories of particular networks and of the ways in which these and the sites of importance to them are interleaved and layered within the traders' identities, sensibilities and commercial practices. In October 2017, I travelled with a trader from Mazar-e Sharif to Andkhuy, a town of about 40,000 souls, and also to the nearby border post of Aqinah, both located in the northern Faryab province.

We had been planning this trip since meeting one another in Tajikistan in the winter of 2009. My friend had told me many stories over the years of the time he had spent working for influential Afghan companies in Turkmenistan in the 1990s. More recently, the Aqinah border has been developed by Afghanistan's government and international funding agencies as part of a strategy to improve trade with Turkmenistan and to open the country's access to European markets by way of a trade transit corridor to Turkey via the Caspian Sea. ${ }^{13}$ At the same time, Andkhuy has been the home of many émigrés - Muslim and Jewish - from Soviet Central Asia since 1917. Close to the border, Andkhuy was a convenient refuge for Bukharan migrants arriving in Afghanistan in the late 1920s. Wealthier migrants mostly left the town, often moving to Kabul; many others stayed - eventually establishing a healthy industry in carpet production, as well as overseeing the trade in Karakul lamb fur, a commodity of critical importance to Afghanistan's exports until the 1970s. ${ }^{14}$ In light of the town's significance for the globalisation of Afghan trading networks, a visit to Andkhuy had long been an ethnographic ambition.

In 2009, we travelled on several occasions to another town that was also home to émigrés from Central Asia, Aqcha. Merchants from Aqcha are active across the Eurasian settings explored in this book. They own supermarket chains in Afghanistan that sell commodities of everyday use imported from Yiwu, run shops in Istanbul's Grand Bazaar that sell Afghan carpets and ersatz 'Afghan jewellery' manufactured in the town or procured by these traders in Nepal and Myanmar and are a visible feature of the bazaars of Jeddah and Dubai, where, as we saw in Chapter 3, they deal in ready-made clothing, machine-made carpets and robes used for conducting the pilgrimage as well as other religious devices, most especially electronic 'prayer beads'.

The road to Andkhuy was in poor condition until 2009, and, unfortunately, our visit to the town never materialised. In October 2017, there

${ }^{13}$ President Ashraf Ghani inaugurated the Lapis Lazuli Corridor in Herat in December 2018.

14 Jalallar 2011. 
were stretches of the road at which Taliban and even purportedly ISISaffiliated militants appeared; however, if we were careful and avoided these places from the afternoon onwards, he suggested that our journey would pass without incident. ${ }^{15}$ That we would travel in the simple car of a joint friend would mean that militants on the road would be unlikely to attack our vehicle - vehicles used by the security forces and border police that ply this route regularly come under attack, not those of civilians.

The verdant foliage that characterises the road as it leaves the urban peripheries of Mazar-e Sharif and passes by the villages of Balkh does not continue indefinitely. About forty-five minutes after leaving Mazar, the road enters the increasingly arid landscape that stretches up to and beyond the border with Turkmenistan. Water is a scarce resource in this part of Afghanistan. While the region's inhabitants - a complex mix of Farsi-, Pashto-, Uzbek- and Turkmen-speaking peoples - are renowned for being industrious and hard workers - as demonstrated in the many roadside brick kilns - the region's youth have for long laboured abroad and sent remittances to their families. ${ }^{16}$ Until the mid-2000s, most labour migration from northern Afghanistan was to Iran - fewer individuals and families also travelled to the Gulf, especially to the UAE and Saudi Arabia, where they worked in the shops, restaurants and warehouses of the émigré traders whose activities were explored in Chapter 3. The poorer Saudi Arabia-based families that are having to return to Afghanistan after living and working in Jeddah and other cities in the Hejaz for over thirty years are mostly returning to their ancestral villages in this region. Over the past five years, increasing numbers of youth have travelled to Turkey, mostly illegally, though sometimes arriving on visas issued to them thanks to the brokerage of powerful figures from this region of Afghanistan who are influential in Kabul and Turkey. Young men such as these often staff the Istanbul-based businesses and

15 Aside from the purported influence of militants including the Taliban and ISIS, political instability in Jowzjan also increased in the wake of the self-exile to Turkey of one of the region's most well-known and powerful politicians: the Soviet-era militia man and Uzbek leader General Rashid Dostum. In the absence of Dostum, and his regular and widely reported assaults on militants, local people often remarked that both ISIS and the Taliban had carved control of important territory in north-western Afghanistan. Discussions of the geopolitical aspects of the conflict in north-western Afghanistan also focus on the role played by the governments of Russia and the various Central Asian states that the region borders. From 2016 onwards, these states were widely assumed by the country's media to be supporting particular factions of the Taliban in order to destabilise US influence in Afghanistan, as well as to act as a defensive force against the encroachment of ISIS into the Central Asian states and Russia beyond.

16 See Hakimi 2020. In addition to receiving migrants from Central Asia in the early twentieth century, the region was also the focal point of state-sponsored Pashtun migration in the late nineteenth century. See Tapper, N. 1973. 
offices of émigré merchants. I first met the Turkmen-speaking Yusuf Aka, for example, in Mazar-e Sharif in 2009 when he was in his mid-teens; I was next able to meet him in the summer of 2017 in Istanbul, a city to which he had travelled along with his wife where he was employed in a travel agency and import-export company run by an émigré merchant and his wife.

The influence of Turkey and Saudi Arabia is clearly visible in the migratory patterns of north-western Afghanistan but also in its built and cultural environment. Sheberghan - the headquarters of the province of Jowzjan - is home to an impressively sized new mosque constructed in recent years by a Turkish construction company. This particular mosque's design is different from the low-key earth brick structures that are commonplace in north-western Afghanistan: Shiberghan's inhabitants are now able to worship in a replica of Istanbul's Ottoman-era 'Blue Mosque'. Local merchants, including the families of those with whom I conducted fieldwork in Yiwu, raised most of the funds, though the traders told me that the Turkish state also made a contribution.

One of the merchants most actively involved in financing the building of the mosque runs a trade and transport company that has offices in Yiwu, Istanbul, Jeddah and Kabul. The family had risen to public significance in Afghanistan in the 1990s when they ran the market complex in Mazar-e Sharif in which the city's substantial foreign exchange services were located. By building ties with the various strongmen active in Mazar at the time, the head of the family was able to provide security to money merchants based in the market while also making considerable profits from money exchange himself. The family were regarded not only as wealthy but also as religious and reputable merchants: they shunned the displays of lavish hospitality used by some merchant families to achieve fame and notoriety and were instead known to strictly follow an ethic that involved them refusing to accept or provide hospitality to others. The family is known for carefully guarding their relations with others a nephew of the merchant who was based in Yiwu during my fieldwork was often talked about in terms of not merely refusing to engage in meetings between Afghan merchants but also shunning their company socially. For some of the traders in Yiwu, the man's reluctance to establish relations with other Afghans in the city was overly guarded; 'It's one thing to follow your uncle's advice and not speak to those you don't know', one trader remarked to me, 'but another to entirely cut off all relations.' In the 2000s, the family used the capital they made in Mazar-e Sharif to expand their trading activities into new commercial fields that emerged in the context of the US-led occupation. The merchant's nephew told two traders from Afghanistan and me in Yiwu, for instance, that his uncle 
had made good profits importing the dog food that was required by NATO to feed the scores of dogs that were brought to the country to clean landmines and search for remote-controlled explosive devices.

Besides being involved in Afghanistan's expanding market in 'war commodities', the family was also able to use connections they had established in Turkmenistan over the prior two decades of Soviet intervention in Afghanistan to become active in that country as well. Companies connected to the family, for example, imported Turkmen oil to Afghanistan; they also acted as agents in exporting heavy machinery to Turkmenistan from China and Japan. By the late 2000s, as Afghanistan's economy shrank in the context of the withdrawal of NATO forces, the family pursued a range of alternative strategies, opening, for example, a supermarket chain selling foodstuffs and 'items of daily use' that targeted Afghanistan's expanding - if precarious - urban middle class. Many of the commodities of 'daily use' sold in this supermarket chain are purchased in Yiwu, hence the family's decision to open an office in the city. Traders in Yiwu often remarked to me that this merchant has for long played an active role in financing religious institutions (especially religious schools, or madrasas) in this region of northern Afghanistan, as well as covering the costs of students from the region seeking religious instruction in the country's urban centres.

We eventually arrived in Andkhuy at around 3 p.m. After a brief stop in Andkhuy, during which time my friend attended the funeral of his relative, we visited a historic mosque complex and looked around the bazaar, seeing the many wholesale shops selling carpets, most of which would be destined for export. We then continued our journey to Aqinah, the border post. The journey took us thirty minutes or so, and we eventually pulled up outside a trading office that also advertised itself as offering shower facilities - the latter being used by truck drivers bringing goods from Turkmenistan to Afghanistan. Stacks of cartons of high-quality cigarettes were a clear indication that the truck drivers also found room in the cabs of their truck to smuggle lucrative items to the bazaars of Turkmenistan. Indeed, as a sandstorm raged outside, our host - who trades in cigarettes across the border and was assisted in the building of his trading office by a loan from my friend - brought us bottles of vodka made in Turkmenistan and plates of fried fish caught in the waters of the nearby Amu Darya (Oxus River). My friend agreed with our host that he would remove the cost of these luxury items from the substantial sum of money owed to him.

In the morning, my friend prepared a fish soup inspired by a famous Russian recipe $(u k h a)$ that he had learned during many years spent in Turkmenistan, a country in which he had also married a woman of 
Ukrainian ancestry and fathered a son (with whom he remained in contact by telephone and sent regular remittance payments to; his eldest son by his Afghan wife had also visited Turkmenistan to spend time with his Russian-speaking half-brother). In addition to being connected to the West Asian corridor, the influence of the forms of mobility and exchange of significance to the activities of traders in the Eurasian corridor is also evident in the thinking and identities of merchant families in northwestern Afghanistan. This underscores the significance of being sited at the interstices of multiple Eurasian geopolitical projects for understanding their lives.

We then drove to the terminal of the railway connecting Aqinah with Turkmenistan; the terminal is mainly used for freighting Turkmen oil into Afghanistan, unlike a similar infrastructural development in the Uzbekistan-Afghanistan border post of Hairatan that Yiwu-based traders used to freight goods by train and truck from China. After the police guarding the terminal had shown us around, we set off back to Andkhuy, visiting the home of my friend's eldest son's in-laws. As we parked the car, our host's eldest son was leaving the home's courtyard. The Taliban had recently arrested and jailed some of his relatives for the role they had played in a land dispute: they had purportedly refused to hand over a portion of a disputed piece of land to their sisters, who, according to Islamic law, were entitled to a share of the property. The man - said by my friend to be brave and fearless - told us that the place he needed to visit to meet the Taliban representatives was only a fifteen-minute motorcycle ride away and that he would be back in time for lunch. As we waited, my friend's son found a bottle of Turkmen vodka hidden in his in-law's house and handed the bottle over to his father. Having lived for several years in Tajikistan and Turkmenistan, my friend was convinced of the value of a 100-gram shot as an anti-hangover cure. A 100-gram shot quickly became the best part of the bottle, and my friend soon fell into a deep sleep as we waited for the return of the man who had paid the visit to the Taliban.

It was not until the early afternoon that my friend awoke, and the elder son of the home had returned from his mission. He had successfully negotiated the release of all but two of his imprisoned relatives. We now needed to return to Mazar-e Sharif as soon as possible if we were to pass through the contested parts of the road before late afternoon. The drive home was largely uneventful, other than the car in which we were travelling breaking down several times. We arrived back in Mazar-e Sharif before nightfall and without any difficulties.

My visit to Andkhuy brought into focus the geopolitical significance of northern Afghanistan both for Turkey and Russia. Merchants are active 
in brokering and mediating relationships between powerful outside powers - such as the Turkish state - and local communities and political leaders, as in the case of Shiberghan's replica 'Blue Mosque'. At the same time, the migratory and familial experiences of mobile families in the region more generally demonstrate the ways in which such geopolitical projects become a part of their everyday lives. Making the visit to Andkhuy was important for methodological reasons because it enabled me to have discussions about the hometown of traders currently based in Saudi Arabia and Turkey, facilitating the exchange of memories about work and life in Afghanistan before they left the country to work elsewhere.

\section{Beyond Remittances: Circulations of Credit, Commodities and People}

The geopolitics of Eurasian connectivity are visible in Afghanistan's political and cultural landscape, and merchants from the country play a significant role in mediating relationships between influential geopolitical projects on the one hand and local populations on the other. Rather than inevitably being on the receiving end of capital flows - be these in the form of remittances sent by its overseas communities or investments by influential states and the companies aligned to them - trading networks comprising Afghans are conduits for multidirectional circulations of capital, commodities and people. As I now explore by way of a discussion of the relationships between individual traders and Afghanistan, a consideration of these circulations questions the peripheral role that the country is often assumed to play in inter-Asian dynamics and connectivity. Traders deploy a range of financial instruments and practices of entrustment to secure access to capital within Afghanistan that helps to make possible the wider circulation of money, people and goods across Eurasia. Both the basis and outcomes of such 'practices of entrustment' are not necessarily, however, enduring bonds or ties of trust. ${ }^{17}$ On the one hand, historians have emphasised the role that 'gut feelings' alongside calculations made about the trustworthiness of others plays in encouraging merchants to enter into risky economic partnerships. ${ }^{18}$ On the other hand, the outcomes of practices of entrustment are often more helpfully understood as reflecting the roles and activities of individuals and networks at specific temporal junctures. In short, the role that practices of entrustment play in forging the social relationships on which trading networks are based is contingent on multiple factors: a change in

\footnotetext{
17 See Shipton 2007. $\quad{ }^{18}$ Mathew 2019.
} 
a person's role or activity in a network also leads to transformations in their relationships with others. The ways in which the traders handle and manage underlying contingency adds a further layer in understanding the durability of commercial networks.

Yama (whom I first met in Tajikistan in 2009) is from a province in southern Afghanistan. He left Afghanistan as a teenager in the early 1990s after the collapse of the pro-Soviet government in Kabul. Today, he is in his early forties and living in the Netherlands. Between 1992 and 1998, Yama lived with his brothers in Pakistan. In 1999, the family moved to Uzbekistan, where they lived and worked until 2009. Between 2009 and 2015, Yama lived in Tajikistan along with his elder brother. In all the settings in which he has lived since 1992, Yama and his family have made a living through trade: they owned a music store in Pakistan and dealt in products sourced in Pakistan in Uzbekistan and Tajikistan.

The conditions of life in Tajikistan were a source of exasperation for Yama when I spent time with him in 2013 in Dushanbe, Tajikistan's capital. During our previous interactions between 2009 and 2013, Yama had talked freely with me about his trading activities (especially the wholesale trade in Pakistani tangerines and Iranian citrus fruits). Yet in 2012 Yama complained that the country's authorities were making life ever more difficult for Afghan trader-refugees such as himself. Afghans registered as refugees in Tajikistan were not permitted to reside in Dushanbe according to official legislation; those who did, he told me, were made to pay frequent bribes (pora; rishwat) by the city's police force. Furthermore, new legislation meant that Afghans living in Dushanbe were required to pay a substantial sum of money each year to extend their official refugee permits. Additionally, Afghanistan received repeated visits from Dushanbe's intelligence services asking for 'road money' ( $\mathrm{rah}$ puli) (to cover the cost of the officials' travel to and from work) and 'guest money' (mehman puli) (to allow the officers to treat their guests according to local standards of hospitality). In addition, the declining value of the Tajik currency (somoni) alongside official restrictions on the activities of unofficial currency dealers (saraf; hawaladar) that were introduced by the country' government in 2015 negatively affected the business activities of Afghans in the country. Traders from Afghanistan are accustomed to being treated as revenue sources by the authorities of Central Asian states. ${ }^{19}$ Against the backdrop of a worsening Tajik economy, however, additional and repeated payments made life for Afghan traders and refugees such as Yama unsustainable.

${ }^{19}$ Marsden 2016: 241-47. 
From Trader to Sojourner: Central Asia's Steppes to the Black Sea

In 2015, Yama travelled from Tajikistan to Ukraine, where he spent some six months in Odessa. During that period, Yama stayed in multiple apartments - one of which was made available to him by the Afghan 'smuggler' (qachaqbar) whom Yama had paid \$3,000 to arrange a Ukrainian entry visa. After the apartment was burgled, Yama decided to rent a flat of his own. Yama assumed that the burglar had known he was carrying a substantial amount of cash because he had been provided with this information by the smuggler. Yama's two young children accompanied him to Ukraine, and he needed to arrange for them to go to a school in Odessa - he was determined that they would not fall behind in their education as he had in Afghanistan and Pakistan in the 1990s.

During his six-month stay in Odessa, Yama would make intermittent visits to the Seventh-Kilometre Market that I introduced in Chapter 2. Most of the approximately 4,000 Afghans based in Odessa either run wholesale businesses in the market (purveying commodities they import to Ukraine from China) or are employed in it by their compatriots (as sellers, labourers and warehouse keepers).

Afghan asylum seekers in Odessa tend to invest the cash with which they travel to Ukraine in a shop in the Seventh-Kilometre Market. Yama decided not to invest any of the capital (sarmaya) that he had brought with him from Tajikistan in a commercial operation in the market. Yama had carried on his person some of the cash that he had brought to Ukraine from Tajikistan. He had transferred more using the services of a Dushanbe-based money exchange agent (saraf) from northern Afghanistan. Yama explained to me that he had not set up a shop dealing in Chinese goods in the market because his priority was to travel - along with his two young children - to Western Europe. If he invested some of the approximately $\$ 100,000$ at his disposal in a commercial operation in Odessa, he told me, his money would have become 'stuck' (band mond) and his ability to move constrained. Yama's transition from a trader (tajir) to an officially designated refugee (muhajir) involved him resisting the temptation to invest capital in a commercial operation.

Yama had also arrived in Ukraine with considerably less capital at his disposal than he had initially hoped. He had entrusted (amanat kardan) a sizeable proportion of the money he had saved in Tajikistan to a Tajikistani trader called Shahid. The two had known one another for nearly twenty years, having initially met in Uzbekistan. Shahid had fled Tajikistan in the context of the country's bloody civil war (1992-97), and the two had established a trading partnership (sharakat); they also worked 
together in Dushanbe after Shahid had returned to Tajikistan from Uzbekistan when conditions had improved in the early 2000s.

In Dushanbe, the men spent much time together, and their business activities (marmalah) became increasingly intertwined. Yama sent Shahid to the Khujand with consignments of tangerines to sell; Shahid was a regular guest in Yama's flat in Dushanbe. Additionally, because Yama was a registered refugee in Tajikistan and was unable to travel outside the country, he entrusted his capital to Shahid, who made use of visa-free travel for Tajikistan citizens to Iran to source products (especially citrus fruits) in Mashhad.

Despite the long-term nature of their relationship and the clear ties of friendship (dusti; rifaqat) as well as the shared experience (tajrubah moshtarak) and sharing of food and space that joined Yama and Shahid, Shahid failed to answer Yama's telephone calls from the day he left Tajikistan. As a result, Yama could not retrieve the savings he had entrusted to Shahid.

Yama faced a similar dilemma with one of his Afghan relatives, his brother's brother-in-law (Aziz). Aged in his mid-thirties, Aziz lived in Kabul, where he and his brothers ran a medium-sized business specialising in the sale of construction materials. Aziz had also traded in tangerines with Yama in Tajikistan. Aziz's business in Kabul had declined in size because of the withdrawal of significant numbers of NATO forces in 2014 and a decline in new infrastructure projects in the country. Against this backdrop, Aziz and his brothers had borrowed money from relatives and friends, including Yama, to keep their business afloat. As with Shahid, Yama told me that Aziz had also not returned his phone calls in the days leading up to his departure for Ukraine.

Yama's difficulty in recovering debts from his transnational network of business associates, friends and kin underscores how an understanding of the dynamics of long-distance trading networks requires recognition of underlying mistrust as well as attempts to fashion trust. Alessandro Monsutti has made a comparable point in his consideration of the significance of trust to family life in Afghanistan, noting, for many Afghans, that 'relatives are not so much people one can trust as people one knows; this makes it possible to take vengeance in case of defection, either by locating them and resorting to physical violence, or by ruining their reputation in a shared social milieu' ${ }^{20}$ Yama's attempts to gather debts (qarz jam kuni) from his close relatives and friends suggest that the threat of physical or reputational vengeance loses its power in contexts characterised by flux, mobility and uncertainty, thereby investing the ability of traders to handle

${ }^{20}$ Monsutti 2013: 152. 
contingency and an atmosphere of mistrust with even greater significance.

\section{Trusted Friends or Unexpected Partners?}

Understanding the calculations that individuals such as Yama make about whom to entrust with their capital in terms of evaluations of longterm relationships of friendship and kinship alone deflects attention from the contingent ways in which the circulation of people and things takes place across expansive spaces such as the Eurasian arena. In Odessa, for example, Yama chose to entrust (amanat kardan) his money to Dil Agha, a man with whom he had neither worked nor enjoyed close (qarib) ties of friendship or kinship. Associates (ashnaha) whom Yama had come to know in Odessa had told him that Dil Agha was reliable and trustworthy. And Yama sought to verify these assessments, telling me how he 'spent time with him on three or four occasions and it appeared he was good'. Far from handing over his cash for safekeeping to a person known to him over a prolonged period or to a close relative, Yama entrusted the cash to Dil Agha - the trader in children's bicycles whom I introduced in Chapter 2 - after only a very brief acquaintance. The existence of a social institution - in this case, the market and the intense forms of familiarity among Afghans that it makes possible - that served as a pool of reliable information about commerce and personal reputation for Afghan traders enhanced his ability to do so.

Given the impromptu nature of Yama's ties to Dil Agha, it is relevant to consider the relationship between the two men in detail.

\section{'Gift by the Donkey Load; Account in Ounces!' Calculation, Trust and Serendipity}

In the context of intense competition between Afghan traders in the market, Dil Agha had used the cash (around \$20,000) entrusted to him by Yama to buy a larger than usual number of bicycles in Yiwu to sell in Odessa; he was sure the bicycles would sell well - they were a new design that had not hitherto been available in the market. The timing of the purchase and arrival of the bicycles was also perfect, he told me: they would arrive in the early spring season, a time of year punctuated by a series of public holidays in Ukraine, when parents buy bicycles as presents for their children.

However, a couple of months after entrusting the money to Dil Agha, Yama told him that he had found a smuggler (qachaqbar) who had agreed to take him and his two children to Europe. Dil Agha told Yama that he 
should not rush to leave Ukraine: it would be wise to wait for a more reliable smuggler who was better known to them before embarking on the dangerous route to 'Europe' with his children. But Yama told Dil Agha that he had made up his mind: he asked Dil Agha to return the cash (paisa-e nurkh) that he had entrusted to him so that he could pay the advance fee (pul-e peshaki) required by the smuggler. Dil Agha told Yama that he would need a few days to get Yama his cash as he had invested it in his business activities. I asked Yama if he had not been worried that Dil Agha would fail to return the money: he replied, citing the Farsi proverb bakhshish ba kharwar, hisab ba musqal (gift by the donkey load and account in ounces). In other words, Dil Agha had demonstrated that he was reliable in that he was an 'exact' (daqiq) person, with a close focus on his accounting practices, rather than on achieving a name through lavish gift-giving. The distinction Yama was making here indexes important distinctions in many merchant communities between new entrants to trade who use lavish gifting and hospitality to stake a claim to reputability and success in the absence of having historical backgrounds in mercantile activity.

\section{Entrusting Property, Returning Capital: Kabul's Property Market}

Having been asked by Yama to return the money as soon as possible, Dil Aga deployed a financial instrument widely used in Afghanistan by property owners to secure access to cash: a giraw. A consideration of the manner in which Dil Agha deployed the giraw to raise the capital he owed Yama provides insights into the way in which, for many traders, including those who rarely if ever travel to the country, Afghanistan is regarded as a context that offers the possibility of securing access to resources and capital. The giraw practice is widely conducted in Afghanistan and other countries in which the dominant legal code is based on the Hanafi School (maslak) of Islamic law; in Afghanistan, it is a recognised legal practice within the part of the country's Ottomaninspired legal code that relates to mortgages (raan). ${ }^{21}$ Giraw entails a property owner handing his or her property to another party for an agreed sum of cash. Upon the return of the cash, the property's original owner reassumes full ownership. While giraw is widely practised in Afghanistan, it is also the source of theological dispute, both in the country and in the wider Muslim world. For Muslims following legal

${ }^{21}$ For a detailed discussion of the relationship between the Afghan and Ottoman legal systems, see Ahmed 2017. On the use of giraw by merchants in Afghanistan and its complex relationship to the country's legal structure, see Rahimi 2019. 
traditions other than the Hanafi School, the practice of giraw (mostly referred to in Arabic as a bay' al-wafa' or 'selling on faithfulness') is regarded as constituting an agreement between seller and buyer to resell a property at the original purchasing price. As the person giving the loan can use the property to make money, scholars from other legal traditions regard giraw as a practice that allows individuals to contravene shari'a stipulations regarding interest (riba, sud).

Afghan traders often point out that the making of regular and rigorous assessments by traders about how far their daily practices relate to Islamic prescriptions is relatively rare. A trader in his early forties who owns a clothing factory in China and a wholesale business in Kabul told me that Islam's role in Afghan traders' business activities should not be overexaggerated, remarking that 'there is much of what we do that Islam tells us not to and it is the same with giraw'. Other traders, however, do follow theological debates about giraw. They generally argue that if the party providing the cash uses the property to house his family, then the giraw is lawful (halal). Should the property, however, be rented out by the buyer to a third party, then this constitutes a mode of making interest (sud) on a loan (qarz) and is therefore impermissible (haram) according to Islamic law.

A consideration of the giraw's use in the case of Dil Agha illustrates less about the role that Islam does or does not play in the modes of commerce in which the traders are involved than the importance of specific practices of entrustment to Afghan trading networks and demonstrates Afghanistan's non-peripheral position in the Eurasian economic geography under consideration here.

In return for receiving $\$ 20,000$, Dil Agha allowed a creditor unrestricted use of his flat in Kabul until the loan had been repaid and a date agreed for the return of the flat. Dil Agha arranged for the money transfer from Kabul to Odessa using a saraf and was able to return Yama his cash by the date on which it was required. Being party to such an agreement involves an important element of risk. This is especially so for an individual such as Dil Agha, who does not live in the country and does not regularly travel there either. While having friends, family and associates in Kabul, Dil Agha does not have access in Afghanistan to the dense social and political networks that individuals permanently based in the country do.

The flat that Dil Agha had put on giraw to raise Yama's money was of great personal significance to him. Dil Agha proudly told me how he had bought the flat in Kabul before the collapse of President Najibullah's regime in 1992. He had initially rented the flat in the Soviet-era microrayon (apartment block area). Eventually, however, a government scheme 
allocated the flat to him in return for a monthly contribution with the prospect of eventual ownership. As with many other government employees, after the collapse of Najibullah's regime, Dil Agha initially remained in Kabul and continued working in his post. During this period, however, the mujahidin leaders who had come to power regularly accused former state officials of corruption, often occupying the properties they owned. According to Dil Agha, however, his positive reputation and willingness to work for a time in the Islamic government meant that - against all odds - he was able to maintain control of his property; the property was not, moreover, merely an important aspect of the 'tangible presence of the absent migrant' as it also allowed him to secure access to the forms of capital required by his inter-Asian trading activities. ${ }^{22}$ Against this context, Dil Agha was intent on returning the loan and reassuming full ownership of the property as soon as possible.

\section{Crossing the Carpathians: From Sojourner to Refugee}

Shortly after Dil Agha received the money from Kabul, Yama left Odessa for the border with Slovakia with his two children, having been instructed to leave by a 'people smuggler'. After staying for several weeks in a hotel in a town near the border, the family successfully travelled to the Netherlands by way of Slovakia, Austria and Germany. Before embarking on the journey, Yama agreed to take with him Dil Agha's brother's son, Karim. Aged in his early twenties, Karim had been working with Dil Agha in his shop on the Seventh-Kilometre Market for the past four years. However, uncle (kaka) and nephew (barodarzada) did not get on well. Karim was of a religious persuasion (mazhabi) and irritated Dil Agha by preaching against alcohol and insinuating that his wife dressed inappropriately for a Muslim. Additionally, three years carrying heavy goods between the warehouse and shops in the Seventh-Kilometre Market had taken its physical toll on Karim: he suffered serious health problems, and Dil Agha advised him either to return to Afghanistan for treatment or to travel on to Europe with Yama and file an asylum case. Yama agreed to pay half of the fee (around $\$ 7,000$ ) requested by the people smuggler - he knew that, despite being in poor health, Karim would be able to help Yama's children (aged ten and thirteen) to traverse what the people smuggler had warned them would be a long and difficult journey across the Carpathian Mountains.

${ }^{22}$ An extensive body of anthropological literature explores the significance of houses in mediating the relationships between migrants and their homelands. See, for example, Dalakoglou 2010. 
Before travelling to Western Europe, Yama entrusted a further tranche of cash to Dil Agha. Over the coming months, Dil Agha transferred Yama's amanat to the Netherlands in instalments using exchange agents (saraf) based in Odessa. When I met with Dil Agha in China in May 2016, he proudly showed me WhatsApp messages informing Yama how much money he had forwarded to him - demonstrating his trustworthiness and commitment to our mutual friend. By the time I met Yama in the Netherlands in November 2017, Dil Agha had sent most of the remaining money to him. Yama, meanwhile, was growing accustomed to the new routines of his life as a 'refugee' supported by a national social welfare system but unable to maintain the life of an independent trader. ${ }^{23}$

Dil Agha took a risk by giving his property to a loan provider based in Kabul and using the giraw as the instrument by which to do so. In the case explored earlier, the transaction was eventually completed: Yama gained access to his savings, which allowed him to move with his daughters to Europe; Dil Agha eventually paid off the debt he owed, and thus recovered ownership of his apartment. However, both men entered into the relationship in the context of experiences of breakdowns of trust: Yama was unable to recover debts from close friends and relatives to whom he had lent money; Dil Agha had come to see how his friends in Odessa had frequently gone against their word during commercial exchanges with him. Furthermore, traders in Afghanistan are acutely aware of the more general risks involved in giraw. The launch of a new Afghan currency in 2001 resulted in many families who had given their property on a giraw basis turning to the country's formal legal system to ensure that the money owed to them was calculated based on the equivalent cost in US dollars rather than local currency. Traders do make careful judgements about whom to entrust with their precious savings. Yet such judgements are based on knowledge gathered about individuals in a specific context as much as they are on the basis of abstract assumptions about the role that pre-existing ties play in enabling individuals to make assessments about the future behaviour of a partner to such an exchange.

\section{Favours and Friendship in Kabul}

Traders play an active role, then, in the circulation of capital, commodities and personnel through the networks in relation to which they operate across Eurasia; in order to do so, they make calculations about whom to trust based on knowledge about traders' reputations that is pooled in social institutions of which they are themselves authors as well as acting

${ }^{23}$ Marsden 2020a. 
upon their 'gut feelings'. As I now explore, traders working in Afghanistan must also engage in specific practices and activities in order to ensure the country is able to function as an important node in wider networks in the manner discussed earlier - such practices and activities enable the building of social relationships in a wider environment characterised by mistrust, political volatility and fragile state institutions. In the ethnographic material presented in what follows, I focus especially on the importance of food and sociality to the building of friendships between traders and security officials - figures who can play an important role in the recovery of loans and capital in the context of breakdowns of trust.

Relationships between merchants and state officials in settings such as Afghanistan are conventionally interpreted through the analytical lens of corruption and bribery. Afghanistan's political and economic dynamics are, indeed, widely analysed by scholars and policymakers alike in relation to discourses of corruption, and the country regularly appears in one or other of the scales used to rank the most corrupt countries in the world. At a general level, traders also talk about the 'system' within which they work as being pervaded by 'institutional corruption' (fesad-e idara), and the payments they make to officials as 'bribes' (rishwat). They also hold nuanced views on government attempts to reduce levels of corruption in the country. On the one hand, they say they pay bribes because there is no alternative - they wish their profits went to state coffers rather than the pockets of corrupt officials. Yet they also argue that legislation introduced by the authorities to reduce corruption actually compels more and more traders to use informal or 'black' (siah) methods. Many traders said that a crackdown by the government on the use of banks to transfer cash out of the country, for example, had resulted in them having to pass through several layers of bureaucracy to move money internationally, eventually resulting in traders using hawala networks for all - rather than a proportion - of their transactions. Finally, traders also distinguish between independent commodity traders and other individuals involved in the provision of contracts for government departments. They often argue that if independent commodity traders - including themselves - do 'circumvent the law', this is largely because of their need to increase profits as much as possible with the aim of establishing a reserve of capital substantial enough to allow them to move their families out of the country in the event of a major breakdown of security. ${ }^{24}$ By contrast, contractors (qaradadiha) were spoken about as making very large sums of money based on their connections (wasita) to key government officials

${ }^{24}$ For the range of activities in which traders engage that require them to work 'outside the law', see Ibañez-Tirado and Marsden 2020. 
(karmandha-ye dawlat) - making money in this way was regarded as difficult (kar-e janjal) but also morally questionable (kharab) work. Indeed, traders in Yiwu often suggest that it is by acting as channels for the 'black money' (pul-e siah) made from government contracts, rather than the sale of commodities themselves, that their compatriots in the city are able to own expensive cars and lead luxurious lifestyles.

Work by anthropologists similarly suggests that the notion of corruption is overly one-dimensional to account for the role played by gifts and exchanges in the making of relationships between commercial personnel and government officials. In an important book, David Henig and Nicolette Makovicky challenge the tendency of social scientists to explore favours through a zero-sum transactional approach. ${ }^{25}$ This way of looking at favours, they argue, ignores the role played by gratuitous behaviour in the making of social relationships - it reduces acts of giving to the calculated expectation of future benefit. We have already seen how many Afghan traders think that a key problem with the notion of trust as it relates to their everyday lives is that it fails to allow for an important aspect of being human: a person's ability to change their mind. For these traders, the notion that a gift will inevitably result in a return is a naive reading of human behaviour. Humphrey has suggested furthermore that analysing favours through a purely transactional lens fails to recognise the 'moral aesthetics of action' that inform such practices. ${ }^{26}$ By using the term 'moral aesthetics', Humphrey is drawing attention to the ways in which the giving of favours does not merely carry out a function but constitutes, rather, a mode of acting that is 'initiatory, "extra", ethical, and gratuitous'. ${ }^{27}$ As such, she suggests, favours might well result in mutually beneficial relationships for those involved, but they also endow 'actors with a sense of standing and self-worth ${ }^{28}$ through bringing into being 'indefinitely lasting relationships' and 'circles of beneficence', ${ }^{29}$ even in the most politically volatile of environments.

\section{Debt Collecting: A fourney into Eastern Kabul}

In November 2016, I journeyed around Kabul with Afghanistan-based merchants seeking to recover a loan - making a series of trips with traders seeking to recover a loan and officials that sought to help them allowed me to better understand the types of social practices and social relationships that are of central importance to the city's ability to function as an inter-Asian commercial node for multiple trading networks.

\footnotetext{
25 Henig and Makovicky 2016. ${ }^{26}$ Humphrey 2016. ${ }^{27}$ Ibid., p. $51 . \quad{ }^{28}$ Ibid.

29 Ibid: 68-9.
} 
Some months earlier, Rauf Baig - a man in his late thirties from Mazar-e Sharif - had made a loan of $\$ 10,000$; however, he had not given the money on the basis of 'gut feelings' or in the absence of making calculations on the trustworthiness of the debtor (qarzdar): his debtor (Sharif), rather, was his wife's sister's husband - a type of kinship relationship referred to in Afghanistan as boja. In much of Afghanistan, the relationship between men who are married to sisters (bojas) falls in between the category of kinship and friendship and is associated with sentiments of closeness, support and trust; on this basis, Rauf Baig told me, he believed that no issues would be raised by his lending the money to Sharif. After requesting the payment of the money on a series of occasions, however, his boja ceased to answer his telephone. Rauf Baig's wife told him that her father had also tried in vain to contact his indebted and missing son-in-law. Indeed, no one in the family was able to locate the part of Kabul in which Sharif was living. Rauf Baig, however, urgently needed access to the money: he was planning on moving from his home in northern Afghanistan (where he lived with his wife and children) to Kazakhstan with the aim of opening a trading office specialising in the export of Kazakh wheat to Afghanistan. Rauf Baig required the money to enable him to pay for an expensive Kazakh visa and also to ensure that he had sufficient cash at his disposal during his initial journey. Participation in the wheat trade in Kazakhstan is widely regarded by traders as a potentially very lucrative commercial activity. Yet the import in wheat from Central Asia is also regarded by traders in Afghanistan as especially high risk and dangerous: Kazakhstan's security forces are said to be hostile in general towards Afghan citizens; more importantly, influential 'mafias' - made-up of wealthy Afghans and local businessmen - hold monopolies over the trade in flour between the two countries. Rauf Baig had decided to take the risk of travelling to Kazakhstan due to the economic difficulties of living in Mazar-e Sharif: he had recently lost his job working for a bank owned by one of the city's major businessmen after it fell into arrears having failed in an application for a lucrative Afghan government contract.

In addition to seeking to open a trading office in Kazakhstan, Rauf Baig was knowledgeable about the trading activities of Afghan merchants in China, especially in Yiwu, and part of the capital he was planning to invest in Kazakhstan had its origins in the trade between China and Afghanistan. His brother (Ilham) - aged in his mid-twenties - had lived in Yiwu for the past three years at the time he lost his money. Ilham had initially worked in Yiwu for an export company run by a Turkmen merchant family from the town of Aqcha in north-western Afghanistan that I introduced in Chapter 3. 
Through his brother's presence in Yiwu, Rauf Baig's family enjoyed close connections to this business family and were aware of the prospects and problems of conducting business in a range of regional locales. In light of this, they were also considering sending a further brother to Ashgabat (Turkmenistan's principal commercial centre and also its capital city) to open a trading office of his own. Doing so would facilitate the flow of Chinese commodities to Turkmenistan and Turkmen oil to Afghanistan.

In order to embark on these courses of action and benefit commercially from the relationships his brother had established, however, Rauf Baig first needed to recover the capital he had lent to his boja. He first turned for advice to one of his close friends in Mazar-e Sharif, Abdullah - the merchant who travelled with me to Andkhuy who identifies as being Turkmen on his father's side and Uzbek on his mother's and has extensive experience of trading in the former Soviet republics of Central Asia. Most recently, Abdullah had run a transport company that arranged the travel of NATO convoys into and out of Afghanistan using 'the northern route' between the country and the Baltic port of Riga. Abdullah informed Rauf Baig that he had close contacts in Kabul's National Directorate of Security (amniyat-i milli), and that if he wished to find his debtor these would be the people most likely to help in a concrete manner. Abdullah had made these contacts during a visit to Delhi a couple of years ago (when his business activities were doing especially well). As I explored earlier, Afghans of a variety of backgrounds travel to hospitals and medical centres in India and Pakistan for urgent treatment - this form of mobility is rarely connected to commercial activity but does add a further layer to the experiences and understandings of inter-Asian connections. Abdullah had travelled to Delhi for a much-needed check-up in a heart clinic some years after having suffered a heart attack. On arriving in New Delhi, he had rented a flat in which to stay for the month he planned to stay in the Lajpat Nagar area of the city, a neighbourhood well known as being a hub for refugees, health tourists and traders and moneylenders from Afghanistan. ${ }^{30}$ As he was waiting in the office of an estate agent, Abdullah told me how he began chatting to another man whom he also recognised as being from Afghanistan, and who, it would transpire, had also come to the city in order to have a heart check-up. The two chatted with one another and agreed that they should rent a flat for the duration of their stay - it would be better and more economical than living alone. In the days that followed, the two men in their fifties enjoyed one another's company, even though their preferred pastimes were markedly different.

\footnotetext{
30 Warsi 2015.
} 
Abdullah's years in the former Soviet republics of Central Asia had contributed to his love of vodka. His newfound friend, Bismillah, while having been an officer in the Soviet-aligned government of the 1980s, had recently become an active participant in the Naqshbandiyya Sufi brotherhood and sought to lead a pious lifestyle. Nonetheless, the two would sit together and eat the delicious meals prepared by Abdullah in the evening (many traders from Afghanistan pride themselves on their ability to cook, learned over years of musafiri [travel and being away from home]). Abdullah would enjoy his meals with a few 'pikes' (glasses) of whisky, while the pious Bismillah, who enjoyed watching the sunrise over the Delhi skyline in the early morning after saying his prayers, would ensure the fresh Afghan bread bought from a local bakery and strong tea were ready for the blurry-eyed Abdullah when he woke in the morning.

Besides creating a close friendship through acts of care and commensality performed against the backdrop of a shared sensibility of mortality, Abdullah also told me how he had prevented his new friend from being ripped off by an unscrupulous Indian doctor. The first Indian doctor whom Bismillah had visited had told him that he urgently needed to have an operation to open his arteries (rag) as they were blocked. On hearing this, Abdullah suggested that Bismillah get a second opinion from a doctor that he had come to know and trust over many years. According to the second doctor's suggestion, Bismillah's condition was treatable by medicine alone, and there was no need for an operation. After spending a month together in Delhi, the men returned to Afghanistan: Abdullah resumed his contracting obligations with NATO, and Bismillah returned to his position in the security forces based in Kabul. Abdullah informed a gathering of men in Bismillah's house in Kabul that he only realised what an important person his friend was when they were leaving for the airport: he had caught a glance of Bismillah's passport, and it turned out that he was a general. In narrating his discovery of Bismillah's influential status in this way, Abdullah was actively rejecting the notion that his relationship with 'the general' was transactional. Instead, he sought to underscore the ways in which an underlying 'moral aesthetic of action' endowed the men and the indefinitely lasting relationship they had established with mutually reinforcing 'standing' and senses of 'self-worth'. ${ }^{31}$

Rauf Baig and Abdullah - with myself in tow - prepared to go to see Bismillah in his home in the north-west of Kabul. But as Bismillah had only recently returned from the haij pilgrimage, it would be impossible to visit empty-handed (dast-e khali). So, alongside a couple of the general's colleagues whom Abdullah had got to know on visits he had made to call

${ }^{31}$ Humphrey 2016: 68-9. 
on his friend subsequent to their Delhi trip, Abdullah and Rauf Baig brought a goat to sacrifice in honour of the general and his having completed the sacred pilgrimage. Abdullah made the choice of lean goat (buz) rather than fatty lamb (gusfand - the meat usually served at such events in Afghanistan), specifically with Bismillah's health and food prohibitions (parhez) in mind, another demonstrable act of care and thought for his friend. While Bismillah would not join them in drinking the Danish vodka, there was no reason why other less piety-conscious people in attendance could not partake in a 'pack' or two in the general's residence - a bottle of Danish vodka (no doubt originating from the Danish embassy) was also procured from a shop known to illegally sell alcohol.

Abdullah and his friend planned to sacrifice the goat in the garden of the general's new home. The house was on a street with extra security arrangements, including a police post and traffic-slowing devices meant to prevent the progress of bomb-laden vehicles. On welcoming us into the house, and being congratulated on his new home, the general mentioned that he had only rented the downstairs part of the house - this was actually rather cramped given that he lived with his wife and three children - but, he said, 'we are people used to leading a simple life, so it poses no problem'. A different family rented the upstairs part of the house. Abdullah immediately remarked that there were few high-ranking generals or officials as honest and true (sadiq) as this general in the entirety of Afghanistan. His honesty, Abdullah surmised, no doubt arose from his training in the years of Afghanistan's communist government in the 1980s: no matter the nature of the crimes committed in war, he said, Afghanistan's communists were free from corruption, noting that 'even Afghanistan's communist-era ambassadors drive taxis in London'. Abdullah and Bismillah consciously enacted and performed their honesty and frugality, implicitly contrasting their ethical qualities to those of highranking security officials in Afghanistan that are widely known to make significant sums of money from corrupt practices (fasad fil ard; fesad-e zamin), especially in government procurement contracts and the illegal trade in narcotics.

After an exchange of pleasantries and recounting once more the story of how a Turkmen-Uzbek trader and Farsi-speaking intelligence official had initially met in New Delhi, preparations got underway for the goat feast. As the goat was to be grilled in the form of kebabs, it would be cooked by the men present rather than being sent to the women of the household to prepare, as might well have been the case if another dish (such as the lamb and rice preparation known as palaw) was on the menu. With the general busy receiving guests to congratulate him on returning from haji, it was 
clear that Abdullah was to be in charge of getting the goat ready: a great deal had already been made, after all, of his cooking abilities by the general himself, who fondly remembered the dishes prepared by Abdullah during their time together in India.

Abdullah and the general's colleagues went outside into the small garden that was sandwiched between the guesthouse and the main road and began to prepare the kebabs while also enjoying a pack of vodka outside the confines of the general's guesthouse. Present too was a cousin of the general who would not drink in front of his uncle but took the opportunity to do so when out of his sight. The men cut and chopped the meat into kebab-size pieces. As it was already getting late, Abdullah decided that a special ingredient - Kiwi fruit - would be added to the marinade - this would ensure that the meat would not be too tough for the general in light of it not having been marinated (aqta kardan) the night before. Kiwi fruit juice had been recommended to Abdullah as an ingredient that softened even the toughest of meat, so several kiwis were peeled and squeezed on to the goat, which was also smothered in onions, garlic and tomato paste - all softening agents used in Afghan cooking. Within twenty minutes, Abdullah was threading the meat on to the skewers before one of the general's colleagues (who had removed his gun holster from under his jacket and placed it on the chair beside the grill) grilled it over hot charcoal. Soon afterwards, Abdullah carried the first pieces of meat to the general and the assembled guests who were sitting with him inside the house. Few could believe that such soft meat could have been goat, though there was also some concern from Abdullah at least about its rather gelatinous nature. Abdullah looked in the direction of the men with whom he had prepared the marinade, commenting that they had put too many Kiwis in the marinade: the fruit was such an effective ingredient in marinades that it had turned the meat into water (aw shud). Despite the disappointment over the marinade, the guests ate the meat alongside further glasses of Danish vodka for those participating in that aspect of the gathering.

After four hours of intense cooking and eating, the conversation finally turned to Rauf Baig's attempts to recover the loan he had made to his boja. Abdullah remarked to the general that he personally had no plans to come to Kabul. It was Rauf Baig who needed to come to the city to track down a defaulter (qarzdar), so he also thought it would be a good opportunity to accompany his friend and congratulate the general on his having returned from hajj. The general thanked Abdullah, immediately asking Ilham about the identity of the loan defaulter and his whereabouts in the city. He then gestured to one of the colleagues working with him to accompany the men to the relevant police station (located in the extreme west of the 
city) - they should contact the local officer of the security services and ask for his assistance in tracking the defaulter, the general instructed the men. Shortly afterwards, the group left the general's house. Abdullah and Rauf Baig informed him they would come again and visit him before returning to Mazar-e Sharif.

The goat sacrifice at the general's home was but the first of many gatherings over the course of the next week as Rauf Baig, Abdullah and their friends in the security services sought to locate Sharif. Having left the general's house, Rauf Baig, Abdullah and I returned to the house of one of Rauf Baig's relatives from Mazar-e Sharif where we slept off the goat and vodka of the afternoon. In the morning, we drove in a car (entrusted to Abdullah for the duration of his stay in Kabul by one of the general's colleagues) in order to pick up a man who was known to the men as being on close terms with Rauf Baig's boja. ${ }^{32}$ The man - a Pashto-speaker from the Pakistan-Afghanistan frontier region known as the Federally Administered Tribal Areas - said he knew the rough location of Rauf Baig's boja's house. Yet he did not wish to join us on the trip: he would lose face before his friend if he was seen escorting Rauf Baig to his door. Abdullah and Ilham told him he had nothing to worry about: he could hide in the back of the car as they looked for the home.

We then drove to the other side of Kabul to find the debtor. Having driven around the streets of houses where Rauf Baig's boja purportedly lived yet having had no luck locating the man - despite asking the local baker (nanwai), a key holder of knowledge among urban communities in Afghanistan - we proceeded to the local police station $(a w z a) .{ }^{33}$ I did not enter the station and instead waited in the heavily guarded car park adjacent to it. After waiting for nearly two hours, the men returned with a National Directorate of Security (NDS) officer, and we all drove back to the area in which it was presumed the defaulter was living and resumed the search. Once again, however, there was little luck with the investigation; as it was now dark, all in the group - including the NDS officer returned to central Kabul, where Rauf Baig took them for a meal of kebab and roast chicken before driving them to their homes.

The next day proceeded along very similar lines, although in the evening the NDS officer, his colleagues and one of Abdullah's friends from the northern city of Kunduz returned to the house in which we were staying for a special meal of palaw-i turkmeni (Turkmen palaw) that Rauf

\footnotetext{
${ }^{32}$ Initially, Abdullah's son - working in a trading office in Kabul at the time - had arranged a large Humvee vehicle for his father's use in Kabul. Abdullah rejected the vehicle, saying that it would draw too much attention to him and his friends and that his son must have been stupid to even think that he could drive around Kabul in such a vehicle.

${ }^{33}$ Bayly 1996.
} 
Baig's relatives had prepared. The palaw was accompanied by several glasses of 'local alcohol' (sharab-e watani) derived from sugar cane; the 'energy drink', as the traders referred to it, which was far cheaper than imported vodka, had been procured from a shop that the NDS officers vouched for as providing safe products. On this occasion, a Pashtospeaker from Kunduz - who worked as a contractor for the Ministry of Defence - joined the Turkmen traders and Dari-speaking security officials. According to Rauf Baig, the man sympathised with the Taliban. There were moments of friction in the encounters that took place, mostly about the various languages they spoke and the extent to which these were accorded equal respect in Afghanistan. Yet there were also repeated expressions of solidarity - the Taliban-inclined Pashtun from Kunduz did not object to the other men partaking of a glass or two of home brew spirit made from sugar cane while he relaxed and enjoyed a cigarette. At the end of the evening, the men rose to bid farewell - only after, however, they had shared their telephone numbers with one another, remarking 'we can be of use to each other if we fall into the wrong hands'.

Despite all the social gatherings and work invested into ensuring their conviviality, little progress was made in locating Rauf Baig's boja. Indeed, Abdullah and Rauf Baig distinguished the nature of their ties with the general from those they had cultivated with the NDS. The evening of goat kebab was framed aesthetically in terms of the lasting and mutually respectful friendship between Abdullah and the general. By contrast, Rauf Baig and Abdullah intimated to me that the delay in finding Sharif was down to the unwillingness of one or other of the NDS officers to complete the task without some form of payment; at least one of the men was directly seeking a bribe (rishwat). Thus, if the form of the favours offered across the days and nights were similar in nature (food suitable for festivals and hard-to-procure alcoholic drinks), then the social, moral and aesthetic quality of the gatherings and the tenor of the relationships between the traders and local officials were categorically different.

After my departure from Afghanistan, Abdullah and Rauf Baig continued trying to locate the debtor for several days, yet, they told me on the telephone, they had eventually returned to Mazar-e Sharif emptyhanded. Ultimately, Rauf Baig's plans also changed: rather than establishing a business in Kazakhstan, he entered the employment of the US military as a translator in their base in Mazar-e Sharif. Abdullah set to work building a sarai (a heavy goods vehicle park with storage facility) on some land he had purchased in the outskirts of Mazar-e Sharif on a road leading to the Turkmenistan border. Having spent considerable resources in ensuring that his son's name appeared on the documents verifying ownership of the land, Abdullah died of a heart attack. 


\section{Conclusion}

Afghanistan plays a powerful and important role in the activities of traders from the country who operate in a range of settings across Asia. This chapter has sought to shed light on the nature of the traders' relationships with Afghanistan, and the practices, skills and social relationships that play a critical role in maintaining their ties to it. I have sought to go beyond thinking about such relationships solely in terms of either remittances or corruption and bribery. Instead, the chapter has illuminated a more multidimensional set of practices and instruments that mediate traders' relationships with Afghanistan, including the use of property for accessing capital and the aesthetics of gift-giving and hospitality. The chapter has also emphasised the need to understand relationships between traders and officials in relation to enduring concepts and features of everyday life, especially those of friendship, the forms of solidarity forged in the context of human mortality and the ethical dimensions of the giving and receiving of favours.

The chapter has contributed to the overall arguments of the book in two specific ways. First, it has brought attention to the alternative geographies that are of significance to trade and exchange across Eurasia. Usually regarded as peripheral or indeed a barrier to regional interconnectivity, Afghanistan plays a critical role in the circulation of commodities, merchant personnel and migrants across Eurasia. We have already seen in Chapter 2 how access to commercially gifted people has enabled the entrenchment of Afghan trading networks in the former Soviet Union and their expansion into Western Europe. The material presented in this chapter raises broader conceptual issues for understanding the role played by trading networks in inter-Asian connectivity. Examining flows of refugees alongside a consideration of the activities of Afghanistan's traders questions the assumption that Afghanistan is peripheral to globalised circulations of finance and commodities. When viewed from the perspective of traders, the country is a vital source of capital for transnational Afghan networks of credit and trust - networks that criss-cross an expansive Eurasian arena and that also extend into the advanced economies of Western Europe. Recognition of the penetration of Afghan networks into multiple contexts brings attention to alternative financial geographies and their nodes, as well as challenging the notion that Afghanistan is merely a point of departure for refugees and migrant labourers. A consideration of such alternative geographies highlights the role played by trading networks and the nodes at which they coalesce in processes of development and in connecting regions rarely thought about in relation to one another. 
The chapter's second specific contribution to the book's argument has concerned the significance of traders' modes of handling interlacing forms of trust and mistrust for understanding the durability of trading networks. The chapter sought to move beyond abstract conceptualisations of trust and mistrust to focus instead on tangible acts of entrustment (amanat kardan). The chapter explored, for example, the giving of cash for safekeeping and the raising of capital on property, as well as bringing attention to the contingency inherent in the manner in which traders cultivate relationships of trust. Hitherto, anthropologists and scholars in related disciplines have sought to understand the significance of trustbased relations to trading networks and commerce in terms of the power of shared ties of kinship, friendship, religion and regional identity in such social formations. They have done so ethnographically by focusing on concepts such as 'closeness' and 'hospitality', thereby revealing the importance of moral work and moral spaces - notably those associated with the provision of hospitality - to forging trust. By bringing attention to the contingent, coincidental and unpredictable interplay of individual and collective trajectories over extended periods of time and across complex geographical and legally diverse realms, the material presented earlier emphasises that social actors do not 'trust' each other in the abstract, but only in relation to specific issues. Because the risks that merchants confront are varied and complex, the types of relationships that they build, and the ways that they do so, are necessarily varied. More than reflecting an assumption that long-term relationships lead to predictable behaviour on the part of trusted individuals, building valuable relationships requires access to reliable information and the willingness of individuals to take advantage of unexpected opportunities by forging ties with people little known to them.

An important dimension of this chapter and those preceding it has been the uses to which traders put food in their attempts to forge the ties upon which their activities depend. In Chapter 7, I explore in detail the role played by food and the eateries in which it is served to the dynamics of trading networks and ask what a consideration of this aspect of the traders' activities also reveals about Afghanistan's cultural influence on inter-Asian sites of interaction. 